\title{
Laser-Patterning Engineering for Perovskite Solar Modules with 95\% Aperture Ratio
}

\author{
Alessandro Lorenzo Palma, Fabio Matteocci, Antonio Agresti, Sara Pescetelli, Emanuele Calabrò, \\ Luigi Vesce, Silke Christiansen, Michael Schmidt, and Aldo Di Carlo
}

\begin{abstract}
Small area hybrid organo-metal halide perovskite based solar cells (PSCs) reached performances comparable to the multicrystalline silicon wafer cells. However, industrial applications require the scaling-up of devices to module-size. Here, we report the first fully laser-processed large area $\left(14.5 \mathrm{~cm}^{2}\right)$ perovskite solar module with an aperture ratio of $95 \%$ and a power conversion efficiency (PCE) of $9.3 \%$. To obtain this result, we carried out thorough analyses and optimization of three laser processing steps required to realize the serial interconnection of various cells. By analyzing the statistics of the fabricated modules, we show that the error committed over the projected interconnection dimensions is sufficiently low to permit even higher aperture ratios without additional efforts.
\end{abstract}

Index Terms - perovskites solar cells, laser processing, solar modules, monolithic interconnections, industrial applications

\section{INTRODUCTION}

$\mathrm{I}^{\mathrm{N}}$ $\mathrm{N}$ In the last few years, hybrid organo-metal halide perovskite based solar cells (PSCs) attracted a growing interest in the photovoltaic (PV) community. This interest is mainly driven by the large Power Conversion Efficiency (PCE) of up to > 22\% on small areas,[1] achieved with simple solution processing. This PCE value is comparably high to thin-film ( $2^{\text {nd }}$ generation $)$ photovoltaics using Cadmium Telluride (CdTe)[1] or Copper Indium Gallium (di)Selenide (CIGS) (PCE =22.3\%).[8] [1] Moreover, the efficiency of lab-scale PSCs have exceeded the PCE of multicrystalline silicon solar cells $(\mathrm{PCE}=21.3 \%)[1]$ and is close to even single crystal silicon solar cells $(\mathrm{PCE}=$ 26.7\%).[2]

PSCs consist of an absorber perovskite layer, which resides between a Hole Transporting Material (HTM) and an Electron Transporting Material (ETM) for the selective extraction of photogenerated holes and electrons, respectively. Perovskites

A. L. Palma, F. Matteocci, A. Agresti, S. Pescetelli, E. Calabrò, L. Vesce, and A. Di Carlo are with CHOSE. - Centre for Hybrid and Organic Solar Energy, Department of Electronics Engineering, University of Rome Tor Vergata, Via del Politecnico 1, 00133, Rome, Italy (e-mail: palma@ ing.uniroma2.it; fabio.matteocci@uniroma2.it; antonio.agresti@uniroma2.it; pescetel@uniroma2.it; emanuele.calabro@uniroma2.it; luigi.vesce@uniroma2.it; aldo.dicarlo@uniroma2.it)

S. Christiansen, Helmholtz Zentrum Berlin für Materialien und Energie (HZB), Hahn-Meitner-Platz 1, 14109 Berlin, Germany (email: silke.christiansen@ helmholtz-berlin.de); Max Planck Institut für die Physik des Lichts, Günther-Scharowsky-Straße 1, 91058, Erlangen, Germany (e-mail: silke.christiansen@mpl.mpg.de) have the $\mathrm{ABX}_{3}$ crystal structure [3] where $\mathrm{A}$ is an organic or inorganic cation such as methylammonium (MA) $\mathrm{CH}_{3} \mathrm{NH}_{3}$, formamidinium (FA) $\mathrm{CHNH}_{2}$, Cesium (Cs), Rubidium (Rb) or a mixing of them $[4,5] \mathrm{B}$ is a metal cation, usually $\mathrm{Pb}$ and $\mathrm{X}$ the halogen (I, Cl, Br, F). Hybrid organo-metal halide perovskite can be deposited via solution processing with carrier diffusion lengths as high as $0.1-1 \mu \mathrm{m},[6],[7]$. Moreover, these layers show a band gap tuneability through the alloying and doping of various $\mathrm{ABX}_{3}$ constituents.[8] The most frequently used HTM is the 2,2',7,7'-Tetrakis-(N,N-di-4-methoxyphenylamino)-9,9'-spirobifluorene (Spiro-OMeTAD),[9-12] typically doped with 4-tert-butylpyridine (TBP) and lithium-bis-(trifluoromethanesulfonyl)imide (Li-TFSI), while $\mathrm{TiO}_{2}$ and $\mathrm{SnO}_{2}$ are the most common ETMs. Two main structures of PSC have been developed so far,[13] the first, resembling the Dye Sensitized Solar Cells (DSSC), considers a mesoscopic layer of oxides, typically $\mathrm{TiO}_{2}$, used as a scaffold for perovskite crystallization, $[10,11,14-16]$ and the second, called "planar heterojunction", $[9,17,18]$ which does not involve the use of a mesoporous scaffold. Variations of these basic architectures have been tested utilizing different material layers. [19, 20]

Following the successful development of PSCs, large area perovskite solar modules (PSMs) have also been designed, fabricated and characterized by several groups. [21-25] The fabrication of perovskite modules needs additional materials and engineering efforts with respect to the small area cells, in particular, the laser patterning required to properly interconnect adjacent cells. [23, 26]

The structure of a typical monolithically connected n-i-p perovskite solar module is shown in Fig. 1. The transparent substrate is usually made of glass or plastic, homogeneously covered with a Transparent Conductive Oxide (TCO), typically fluorine doped $\mathrm{SnO}_{2}$ (FTO) or indium tin-oxide (ITO). The vertical lay-

M. Schmidt is with Lehrstuhl für Photonische Technologien, Friedrich-Alexander-Universität Erlangen-Nürnberg, Konrad-Zuse-Straße 3/5, 91052, Erlangen, Germany (e-mail: michael.schmidt@lpt.uni-erlangen.de)

The CHOSE team gratefully acknowledges the project funding of PERSEO"PERrovskite-based Solar cells: towards high Efficiency and lOng-term stability" (Bando PRIN 2015-Italian Ministry of University and Scientific Research (MIUR) Decreto Direttoriale 4 novembre 2015 n. 2488, project number 20155LECAJ) and the European Union's Horizon 2020 Framework Program for funding Research and Innovation under Grant agreement no. 653296 (CHEOPS) for funding.

S.C. acknowledges funding by the German research foundation (DFG) within the CRC951, HIOS. 
out comprises of the transparent substrate, the ETM, the perovskite absorber, the HTM and finally the back contact (usually gold).

Owing to the not negligible sheet resistance (around $10 \mathrm{Ohm} / \square$ ) of TCO, [27] the substrate is divided into sub-cells, connected in series, realizing a monolithic interconnection scheme,[23, 28 ] as shown in Fig. 1. In this way, the substrate is composed of active areas where light absorption and thus photovoltaic energy conversion occurs and dead-zones where interconnection between adjacent cells takes place. We can define the Active Area (AA) as that part of the substrate for energy conversion and a Dead Area (DA) that is responsible for interconnection of cells without contributing to energy conversion, as shown in Fig. 1, where the relative widths $\left(\mathrm{W}_{\mathrm{A}}, \mathrm{W}_{\mathrm{D}}=2 \mathrm{SA}+\mathrm{P} 1+\mathrm{P} 2+\mathrm{P} 3\right)$ are highlighted. Therefore, it is possible to define the Aperture
Ratio $(A R)$ as $A R=\frac{W_{A}}{W_{D}+W_{A}}$, where the sum of $W_{D}$ and $W_{A}$ is defined as Aperture Area width.

In this way, we can define an Aperture PCE (APCE) as the product of $\mathrm{AR}$ and $\mathrm{PCE}$ over active area $(A P C E=A R * P C E)$, giving information on the actual exploitation of the module area.

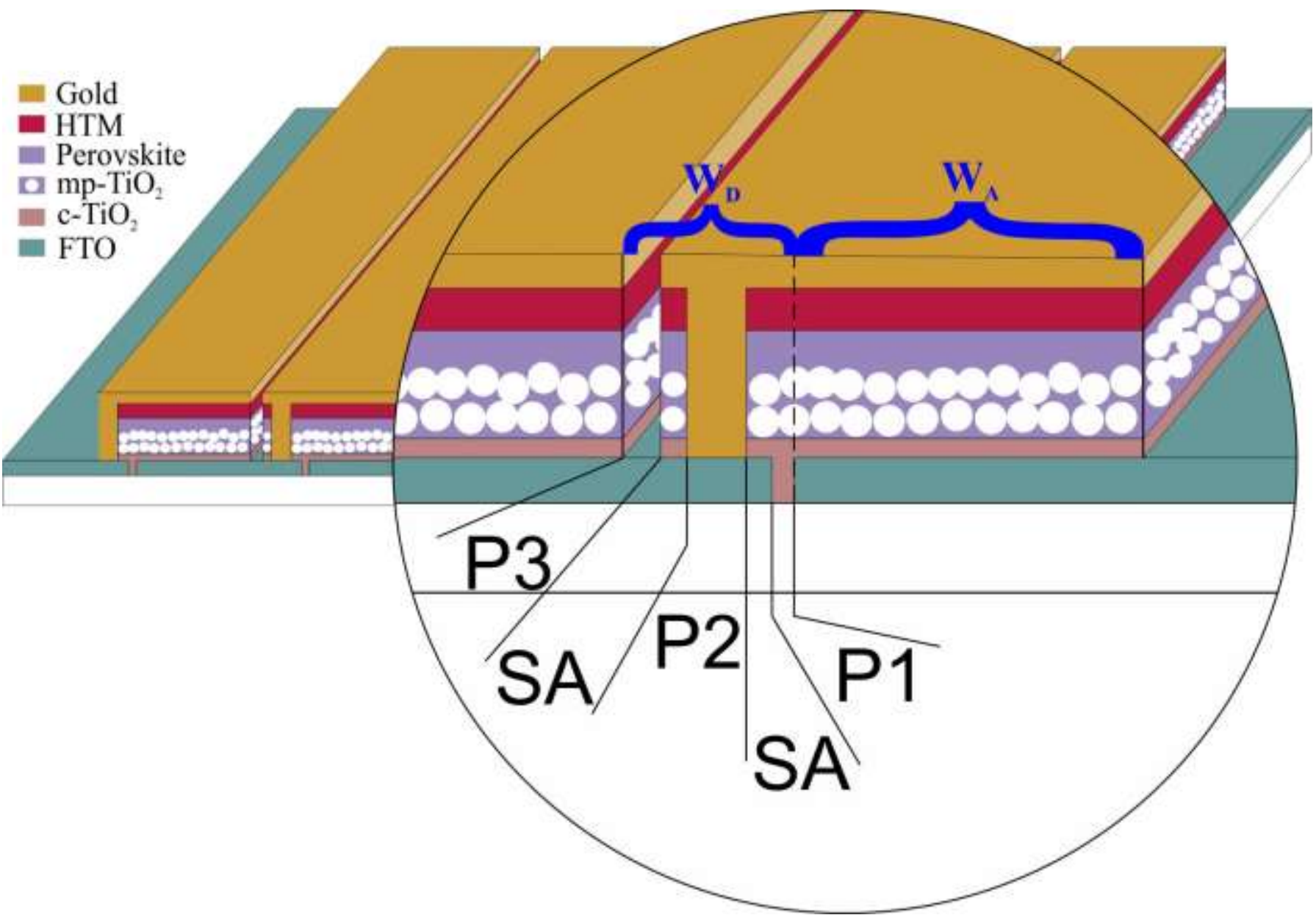

Fig. 1. Schematic representation of a mesostructured n-i-p PSM. In the zoomed circle, an Active Area Width (W Area Width $\left(\mathrm{W}_{\mathrm{D}}\right)$ are highlighted. The latter is formed by the P1, P2 and P3 processes lines and by the two Safety Areas (SA) between these.

Several patterning approaches have so far been demonstrated successfully for PSMs, [23, 29, 30]. However, laser patterning is the preferred choice for industrial exploitation of this technology since it has been optimized for second generation technologies already [31] and this technique provides for the best trade-off between manufacturability and minimized dead areas (DAs). [32] Generally, laser patterning in thin-film PV consists of three subsequent laser processes and thus, the process of laser-induced interconnection of solar cells in modules is called the $P 1-P 2-P 3$ process. [31, 33-36] This approach permits the creation of a monolithic series-interconnected module. Through the P1-P2-P3 laser processing selective layer removal can be realized where required. Typically, the $\mathrm{P} 1$ process insulates the photo-anodes of neighboring cells for series connection. The P2 patterning step separates entire layer stacks of adjacent cells to permit their series connection through subsequent deposition 
of a contacting material, here gold.. Finally, the gold counterelectrode is deposited on the entire module and the P3 laser step is required to separate adjacent cells.

A laser patterning was applied to the first PSM in early 2014 showing a PCE of $5.1 \%$ on an AA of $16.8 \mathrm{~cm}^{2}$, and an AR of $67 \%$.[21] A Nd: $\mathrm{YVO}_{4}$ raster scanning laser $(\lambda=1064 \mathrm{~nm})$ was used to pattern the FTO, realizing the P1 patterning step, while a lift-off technique was applied to remove the compact $\mathrm{TiO}_{2}$ (c$\mathrm{TiO}_{2}$ ) ETM on the interconnection areas. After the deposition of patterned mesoporous $\mathrm{TiO}_{2}\left(\mathrm{mp}-\mathrm{TiO}_{2}\right)$ layers applying screen-printing, a $\mathrm{CH}_{3} \mathrm{NH}_{3} \mathrm{PbI}_{3-\mathrm{x}} \mathrm{Cl}_{\mathrm{x}}$ perovskite layer was deposited, followed by a doped poly(3-hexylthiophene-2,5-diyl) (P3HT) HTM layer. These two last active layers were manually removed from the interconnection area between cells using a mixture of $\mathrm{N}, \mathrm{N}$-dimethylformamide and chlorobenzene. The latter manual step was responsible for a non-optimal AR. In the middle of 2014, Seo et al. have reported a ten-cell PSM with $\mathrm{AA}=60 \mathrm{~cm}^{2}, \mathrm{PCE}=8.7 \%$ and $\mathrm{AR}=75 \%$. [22] This module was based on a planar heterojunction PEDOT:PSS/ $\mathrm{CH}_{3} \mathrm{NH}_{3} \mathrm{PbI}_{3} / \mathrm{PCBM}$ structure but no details were given about the patterning technique. In the end of 2014, the Tor Vergata research group reported a $10.1 \mathrm{~cm}^{2} \mathrm{PSM}$ with PCE $=13 \%$ and $\mathrm{AR}=70 \%$.[23] The performance improvement with respect to the previously reported PSM [21] was related to an efficient double step deposition of the $\mathrm{CH}_{3} \mathrm{NH}_{3} \mathrm{PbI}_{3}$ perovskite and to the adoption of a raster scanning $\mathrm{Nd}: \mathrm{YVO}_{4}$ laser at $\lambda=$ $532 \mathrm{~nm}$ for the removal of the perovskite and HTM layers from the interconnection areas, after the application of a lift-off technique for the $\mathrm{c}-\mathrm{TiO}_{2} \mathrm{ETM}$. The choice of this wavelength for the P2 step is due to the high absorption coefficient of the adopted iodine based perovskite material in that spectral region and the simultaneous high transparency of the TCO. In this way, it is possible to selectively remove the perovskite and HTM from the interconnection regions, without damaging the TCO and leaving the latter surface free to receive the evaporated counter-electrode of the next cell (in a series connection), as shown in Fig.1, realizing a low-resistance vertical contact. [29, 37, 38]

Razza et al. [24] reported the first PSM to have an AA $=100$ $\mathrm{cm}^{2}$, that showed a PCE $=4.3 \%$ and an $\mathrm{AR}=73 \%$, adopting P3HT as HTM. The realization of this large PSM required the adoption of an airflow-assisted blade coating technique to deposit the active layers while the laser patterning was based on the use of a $\mathrm{CO}_{2}$ laser $(\lambda=10600 \mathrm{~nm}$, Pulse duration: $53.4 \mu \mathrm{s})$ for a rapid prototyping. Subsequently, a Spiro-OMeTAD HTM was used and a $\mathrm{Nd}: \mathrm{YVO}_{4}$ raster scanning laser $(\lambda=532 \mathrm{~nm})$ was used to remove perovskite and HTM layers from the interconnection areas. These modifications brought the PCE of the $\mathrm{AA}=100 \mathrm{~cm}^{2}$ and $\mathrm{AR}=73 \%$ module to $\mathrm{PCE}=9 \%$.[39] A similar production procedure has been used recently for the fabrication of a PSM based on graphene interface engineering (GIE).[25] Here, graphene flakes have been dispersed into the mesoscopic $\mathrm{TiO}_{2}$ while lithium neutralized graphene oxide (GO-Li) has been deposited onto $\mathrm{mp}-\mathrm{TiO}_{2}$ as interfacial layer between the perovskite absorber and the ETM. The module presented $\mathrm{AA}=50.56 \mathrm{~cm}^{2}, \mathrm{AR}=73 \%, \mathrm{PCE}=12.6 \%$ and a superior lifetime with respect to a reference standard PSM without graphene could be obtained.

In 2015, the CHOSE team reported the first PSM fabricated by solution processing of the perovskite onto vertically aligned $\mathrm{TiO}_{2}$ nanorods (NRs) as ETMs where a semi-P1-P2-P3 laser patterning procedure was adopted.[40] Here, a two-step P2 was employed, by means of a Nd: $\mathrm{YVO}_{4}$ raster scanning laser. First at $\lambda=1064 \mathrm{~nm}$ the laser was used to remove the $\mathrm{TiO}_{2} \mathrm{NRs}$ from the interconnection areas and subsequently the $\lambda=532 \mathrm{~nm}$ laser line was applied to remove perovskite and HTM layers. Finally, a mask assisted gold evaporation completed the devices. This laser procedure was, also, implemented in the realization of $\mathrm{TiO}_{2}$ NRs based perovskite solar modules [41] adopting vacuum-vapour assisted sequential processing (V-VASP) [15] for the $\mathrm{CH}_{3} \mathrm{NH}_{3} \mathrm{PbI}_{3}$ film deposition. Afterwards, Moon et al. reported the first application of a full P1-P2-P3 laser patterning procedure for a $\mathrm{PSM}$, obtaining a $\mathrm{PCE}=6.6 \%$ on an $\mathrm{AA}=5$ $\mathrm{cm}^{2}$ with an $\mathrm{AR}=84 \%$.[29] In this case, the $\mathrm{P} 1$ was realized on a 20-nm-thick c- $\mathrm{TiO}_{2}$ deposited over an FTO covered glass substrate, using a $\lambda=355 \mathrm{~nm}$, nanosecond pulse laser to insulate the c- $\mathrm{TiO}_{2} / \mathrm{FTO}$ stack, realizing $74 \mu \mathrm{m}$ wide lines. The $\mathrm{P} 2$ scan, realized with a Newport Explorer, $\lambda=532 \mathrm{~nm}$, nanosecond pulse laser, was applied to remove $20-\mathrm{nm}-\mathrm{c}-\mathrm{TiO}_{2} / \mathrm{nc}-$ $\mathrm{TiO}_{2} / \mathrm{CH}_{3} \mathrm{NH}_{3} \mathrm{PbI}_{3} /$ Spiro-OMeTAD, realizing a $180 \mu \mathrm{m}$ wide scribe. After that step, $200 \mathrm{~nm}$ of gold were evaporated and, finally, the $\lambda=532 \mathrm{~nm}$ laser system was used to realize the P3 step and insulate the counter-electrodes.

Recently, Spyropoulos et al. reported a very small area perovskite module ( $\mathrm{AA}=0.3 \mathrm{~cm}^{2}$ ), basically composed by two small area planar heterojunction PSCs connected in series.[42] The authors realized a $\mathrm{P} 1-\mathrm{P} 2-\mathrm{P} 3$ procedure in which the $\mathrm{P} 3$ step has been made by means of a depth-resolved laser patterning over a laminated counter-electrode. The fluence and depth of the focal point inside the material had to be controlled to avoid damage to the plastic substrate and of the counter-electrode. However, despite showing a good $\mathrm{AR}=91 \%$, the performance of such a small area device was limited to a PCE $=9.75 \%$, mainly due to the poor conductivity of the laminated counter-electrode that probably, on a proper size module (e.g. $10 \mathrm{~cm}^{2}$ ), would have decreased its performance.

In addition to the laser procedure, Qiu et al. reported a small area perovskite module $\left(\mathrm{AA}=3.64 \mathrm{~cm}^{2}\right)$ showing a PCE $=$ $14.9 \%$ and $\mathrm{AR}=91 \%$ for which a mechanical blade assisted P1-P2-P3 procedure was adopted.[30] There are, however, some drawbacks for this patterning solution. [43] First of all, since the scribing has been executed in inert atmosphere, the implementation in a production line could present an implementation and most probably in addition a cost issue. Additionally, the micro blade directly enters in contact with the devices causing mechanical stress within the substrate and most probably the formation of abraded particulates, some of which possibly remain attached to the blade, influencing the subsequent blade passes. The same research group recently reported a comparison between the blade-assisted process and the laser-processing one of modules, [32] showing a small area module (AA $=4 \mathrm{~cm}^{2}$ ), with $\mathrm{AR}=93 \%$ and $\mathrm{PCE}=15.3 \%$, for blade assisted $\mathrm{P} 1-\mathrm{P} 2-\mathrm{P} 3$, and $\mathrm{AR}=94 \%, \mathrm{PCE}=15 \%$, for the laser based patterning. 
Even if the latter is the highest AR so far reported, it is clear that realizing a small AA module requires an effort that cannot be compared to the one needed for larger PSMs $\left(>10 \mathrm{~cm}^{2}\right)$. In fact, besides the increase in complexity of deposition techniques when the module area is increased, [20] the realization of tight and controlled DAs on the entire lengths of a module becomes quite challenging. To better address this problem, it is possible to define an Active Area Indexed Aperture PCE (AIAPCE) as $A I A P C E=A A * A P C E$. Thereby, metrics are defined to compare different PSMs, thereby, taking into account the efforts made for the realization of large modules with reasonable AR. This comparison is presented in Table I, where, for all the PSMs reported so far, the interconnection realization techniques and the performance in terms of AR, PCE, APCE and AIAPCE are shown for direct comparison.

In this work we describe a detailed optimization of the P1-P2P3 laser process suited for the fabrication of large area PSMs $\left(\mathrm{AA}=14.5 \mathrm{~cm}^{2}\right)$ with an $\mathrm{AR}$ as high as $95 \%$.

TABLE I

COMPARISON OF P1-P2-P3 REALIZATION TECHNIQUES AND PERFORMANCE OF ALL THE PSMS REPORTED SO FAR (CHRONOLOGICAL ORDER).

\begin{tabular}{|c|c|c|c|c|c|c|c|c|}
\hline $\begin{array}{l}\text { Author } \\
\text { [Ref] }\end{array}$ & $\mathrm{P} 1$ & $\mathrm{P} 2$ & P3 & $\begin{array}{c}\mathrm{AA} \\
{\left[\mathrm{cm}^{2}\right]}\end{array}$ & $\begin{array}{l}\text { AR } \\
{[\%]}\end{array}$ & $\begin{array}{c}\text { AA } \\
\text { PCE } \\
{[\%]}\end{array}$ & $\begin{array}{c}\text { APCE } \\
{[\%]}\end{array}$ & $\begin{array}{l}\text { AIAPCE } \\
{\left[\% \cdot \mathrm{cm}^{2}\right]}\end{array}$ \\
\hline $\begin{array}{c}\text { Matteocci } \\
{[21]}\end{array}$ & Laser & $\begin{array}{c}\text { Lift-off } \\
+ \\
\text { Chemical etching } \\
\end{array}$ & Mask & 16.8 & 67 & 5.1 & 3.4 & 57.12 \\
\hline Seo [22] & N/A & N/A & N/A & 60 & 75 & 8.7 & 6.5 & 390 \\
\hline $\begin{array}{c}\text { Matteocci } \\
\text { [23] }\end{array}$ & Laser & $\begin{array}{c}\text { Lift-off } \\
+ \\
\text { Laser }\end{array}$ & Mask & 10.1 & 70 & 13 & 9.1 & 91.91 \\
\hline $\begin{array}{c}\text { Razza } \\
\text { [24], [39] }\end{array}$ & Laser & $\begin{array}{c}\text { Lift-off } \\
+ \\
\text { Laser }\end{array}$ & Mask & 100 & 73 & 9 & 6.57 & 657 \\
\hline $\begin{array}{c}\text { Fakharuddin } \\
{[40]}\end{array}$ & Laser & Two steps Laser & Mask & 10.8 & 73 & 10.5 & 7.67 & 82.84 \\
\hline Moon [29] & Laser & Laser & Laser & 5 & 84 & 6.6 & 5.52 & 27.6 \\
\hline $\begin{array}{c}\text { Spyropoulos } \\
{[42]}\end{array}$ & Laser & Laser & Laser & 0.3 & 91 & 9.75 & 8.87 & 2.66 \\
\hline Qui [30] & Laser & $\begin{array}{c}\text { Mechanical } \\
\text { (blade) }\end{array}$ & $\begin{array}{c}\text { Mechanical } \\
\text { (blade) }\end{array}$ & 3.64 & 91 & 14.9 & 13.56 & 49.36 \\
\hline $\begin{array}{c}\text { Rakocevic } \\
\text { [32] }\end{array}$ & Laser & Laser & Laser & 3.76 & 94 & 15 & 14.1 & 53 \\
\hline Agresti [25] & Laser & $\begin{array}{c}\text { Lift-off } \\
+ \\
\text { Laser }\end{array}$ & Mask & 50.56 & 73 & 12.6 & 9.2 & 465 \\
\hline $\begin{array}{c}\text { Palma } \\
\text { [This work] }\end{array}$ & Laser & Laser & Laser & 14.5 & 95 & 9.3 & 8.84 & 128 \\
\hline
\end{tabular}

\section{EXPERIMENTAL DETAILS}

\section{A. Laser patterning}

To realize the $\mathrm{P} 1, \mathrm{P} 2$ and $\mathrm{P} 3$ processes we adopted the laser parameters described below in Results and Discussion Section.

\section{B. Devices Realization}

We cleaned the P1 patterned substrates in an ultrasonic bath, using detergent with de-ionized water, acetone and isopropanol (10 minutes for each step). A $50 \mathrm{~nm}$-thick c-TiO ${ }_{2}$ layer was deposited onto the patterned FTO using spray pyrolysis according with a previously reported procedure.[23] $\mathrm{TiO}_{2}$ paste (18NR-T paste, Dyesol) diluted with ethanol $(1: 5 \mathrm{w} / \mathrm{w})$ was deposited over the c- $\mathrm{TiO}_{2}$ surface by spin coating (1700 rpm for $20 \mathrm{~s}$ ) and sintered at $450{ }^{\circ} \mathrm{C}$ for $30 \mathrm{~min}$ to obtain the mesoporous structure. The final thickness was measured by profilometer (Dektak, Veeco 150) to be $200 \pm 20 \mathrm{~nm}$. To obtain the perovskite solution, 1:1 molar ratio of $\mathrm{PbI}_{2}$ (Sigma Aldrich) and $\mathrm{CH}_{3} \mathrm{NH}_{3} \mathrm{I}$ (Dyesol) were dissolved in 1:9 volume ratio of DMSO and DMF at an $878 \mathrm{mg} / \mathrm{ml}$ ratio, and stirred overnight at ambient temperature. $65 \mu \mathrm{l}$ of the solution were spin-coated on the $\mathrm{TiO}_{2}$ substrate at $1000 \mathrm{rpm}$ for $10 \mathrm{~s}$ and $5000 \mathrm{rpm}$ for 45 s. $750 \mu$ of Diethyl Ether (DEE) were poured on the device 12 $\mathrm{s}$ after the beginning of the second spin coating step. Then, the perovskite conversion was obtained after two annealing steps in air, at $50{ }^{\circ} \mathrm{C}$ for $2 \mathrm{~min}$ and, then, at $100{ }^{\circ} \mathrm{C}$ for $10 \mathrm{~min}$. Furthermore, the doped Spiro-OMeTAD solution $(60 \mathrm{mM}$, Lumtec) in chlorobenzene was blade coated on the perovskite layer. The 
molar ratios between the dopants and the Spiro-OMeTAD were 0.5, 3.3 and 0.03 for Li-TFSI, TBP and cobalt additive (FK209) respectively, as reported elsewhere.[44] The P2 treated samples were introduced into a high vacuum chamber $\left(10^{-6} \mathrm{mbar}\right)$ to thermally evaporate Au back contacts (nominal thickness 200 $\mathrm{nm})$. Finally, the samples were subjected to the P3 laser process.

\section{Electrical characterization}

To measure the electrical output of the modules, we used a Class A solar simulator (ABET Sun 2000) at 1 sun illumination conditions and a Keithley 2420 source-meter to record currentvoltage curves. The system was calibrated using a reference Silicon cell (RERA Solutions RR-1002).

\section{RESULTS AND DISCUSSION}

\section{A. P1 Process}

The TCO patterning was realized by means of a Nd: $\mathrm{YVO}_{4}, \lambda=$ $1064 \mathrm{~nm}$ raster scanning laser (BrightSolutions, Luce 40) with a repetition rate $(\mathrm{rr})=30 \mathrm{kHz}$ and a pulse length $=15 \mathrm{~ns}$. To maximize the AR, we optimized the laser pattering to make DA as small as possible, guarantying photo-anodes insulation. We used a fluence of $11.54 \mathrm{~J} / \mathrm{cm}^{2}$, realizing a $44 \mu \mathrm{m}$ scribe through a single laser pass. The measured insulation resistance between subsequent photo-anodes was higher than the detection limit of our instrument (Keithley 2420, >200 M $\Omega$ ), providing a full isolation.

\section{B. P2 Process}

As described in the introduction, the $\mathrm{P} 2$ process removes the entire ETM/Perovskite/HTM (EPH) stack in order to series connect two adjacent cells with the subsequent electrode deposition. To realize a high AR and to easily scale the P2 to real module sizes, a laser assisted $\mathrm{P} 2$ process is the preferred solution with respect to the lift-off technique cited above.[23] To reduce the contact resistance of the series interconnection, a complete removal of the EPH stack is strictly requested without compromising the TCO. [23] To this end, a common practice to evaluate the laser ablation threshold of a material consists in the realization of several laser spots with different fluences and number of pulses. [45] By evaluating the spots diameter, analysing the optically induced phase transformation of the material subjected to the laser process, it is possible to find an ablation parameters window that permits to remove a specific material without damaging the underneath substrate. In our case, the P2 step is applied to a heterogeneous stack of materials, where the $\mathrm{c}-\mathrm{TiO}_{2}$ ETM presents a strong adhesion to the TCO layer. [46] This makes it quite difficult to choose the correct spot diameter of the laser to ensure the correct removal of the entire EPH stack without damaging the TCO. [23] This is a necessary condition to limit the contact resistance between the $\mathrm{Au}$ electrode and the TCO after the P2 step. In this work we use the Transfer Length Method (TLM), [23, 37, 38, 47, 48] to evaluate this contact resistance. The TLM is applied measuring the re- sistance between pads of Au deposited at different inter-distances on the TCO left after the P2 process. [23] Applying a linear fitting to the obtained resistance-distance plot it is possible to extract parameters such the transfer length $\left(\mathrm{L}_{\mathrm{T}}\right)$, the contact resistivity $\left(\rho_{C}\right)$ and sheet resistance $\left(\mathrm{R}_{\square}\right)$.

Two different Nd: $\mathrm{YVO}_{4}$ laser wavelength was considered for the $\mathrm{P} 2$ process, namely the near IR line at $1064 \mathrm{~nm}$, already used for the P1, and the UV line at $355 \mathrm{~nm}$.

The $\mathrm{P} 2$ process with the $\mathrm{Nd}: \mathrm{YVO}_{4}$, raster scanning laser at $\lambda=$ $1064 \mathrm{~nm}$ was applied to a complete stack of materials, composed by $\mathrm{FTO} / \mathrm{c}-\mathrm{TiO} 2 / \mathrm{mp}-\mathrm{TiO} /$ perovskite/Spiro-OMeTAD. Unfortunately, owing to the small absorption of the stack at this wavelength we were not able to find the correct operative window to remove all the layers without ruining the FTO. We should consider that the spray pyrolysis deposition makes the c- $\mathrm{TiO}_{2}$ adhere so tightly to the FTO that the removal results very difficult at this wavelength with the nanoseconds laser we adopted in the previous works.[23, 25] On the other hand, this perfect adhesion is probably one of the causes of the higher current density shown by our PSM reported in Ref. [23] compared to those reported by others,[29] using a $20 \mathrm{~nm}$ RF sputtering deposited $\mathrm{c}-\mathrm{TiO}_{2}$.[49]. For this reason, we decided to keep using the spray pyrolysis deposition technique, finding a different solution for the realization of the $\mathrm{P} 2$ procedure.

We should point out, however, that the Nd: $\mathrm{YVO}_{4},(\lambda=1064$ $\mathrm{nm})$ laser could be used to remove $\mathrm{c}-\mathrm{TiO}_{2}$ in the glass/FTO/c$\mathrm{TiO}_{2}$ stack, but a very tight window around a laser average power of $50 \mathrm{~mW}$ was found to efficiently remove the $\mathrm{c}-\mathrm{TiO}_{2}$, leaving the conductive oxide layer unaltered. This specific P2 process could be considered for module pattering, however, a subsequent step (P2"') is needed to remove the perovskite/HTM layer with an additional alignment procedure. To perform such alignment, a larger safety area should be considered, increasing the overall width of the DA and consequently reducing the AR. In order to eliminate the peculiar limitations of the near-IR P2 laser patterning, we performed the $\mathrm{P} 2$ with a UV laser considering that the absorbance of $\mathrm{TiO}_{2}$ at $\lambda=355 \mathrm{~nm}$ is $\sim 2.5$ times of the one of FTO, while for $\lambda=1064 \mathrm{~nm} \mathrm{TiO}_{2}$ and FTO have a similar absorption.[50]

A $10 \mathrm{ps,} \mathrm{Nd}: \mathrm{YVO}_{4}$, raster scanning laser, with a $\lambda=355 \mathrm{~nm}$ (Time-Bandwidth Duetto) was used for the P2 process to remove the EPH. The application of a ultra-short pulse laser permits the ablation of materials maintaining a very low heat diffusion through the target, since the time needed for the heat transfer from energized electrons to the lattice ions is in the order of nanoseconds[51] and an adequate picoseconds laser pulse power can evaporate irradiated material before heat transfer takes place.[26, 51, 52]

Using a lens with a focal length of $150 \mathrm{~mm}$, a beam waist $\mathrm{w}_{0}=$ $15 \mu \mathrm{m}$, and tuning the raster scanning speed, the raster scanning lines distance (RSD), and the laser fluence, we realized different TLM measurements to find the optimized process as shown in Fig. 2. Considering an RSD of $15 \mu \mathrm{m}$, a laser moving stage speed of $300 \mathrm{~mm} / \mathrm{s}$ and laser fluence of $417 \mathrm{~mJ} / \mathrm{cm}^{2}$ we obtained, as a best result, a $L_{T}=0.93 \mathrm{~mm}, R_{\square}=8.7 \Omega / \square, \rho_{C}=7.65$ $\Omega \cdot \mathrm{mm}^{2}$. These values compare well with TLM measurements on unprocessed FTO $\left(\mathrm{L}_{\mathrm{T}}=0.7 \mathrm{~mm}, \mathrm{R}_{\square}=7.2 \Omega / \square, \rho_{\mathrm{C}}=3.3\right.$ 
$\left.\Omega \cdot \mathrm{mm}^{2}\right) \cdot[23]$

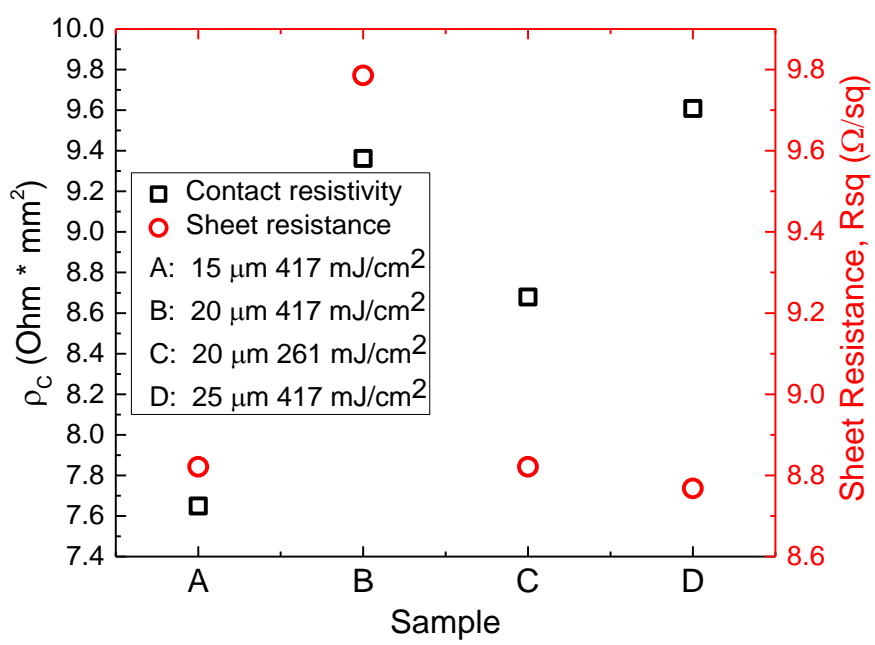

Fig. 2. Contact Resistivity and Sheet Resistance for several Laser parameters as obtained with TLM measurements performed after the P2 process with UVLaser $(\lambda=355 \mathrm{~nm})$ on the Glass/FTO/c-TiO2/mp-TiO2/perovskite/SpiroOMeTAD. A: RSD $=15 \mu \mathrm{M}$, Fluence $=417 \mathrm{~mJ} / \mathrm{cm}^{2}, \mathrm{~B}: \mathrm{RSD}=20 \mu \mathrm{M}$, Fluence $=417 \mathrm{~mJ} / \mathrm{cm}^{2}, \mathrm{C}: \mathrm{RSD}=20 \mu \mathrm{M}$, Fluence $=261 \mathrm{~mJ} / \mathrm{cm}^{2}, \mathrm{D}: \mathrm{RSD}=25 \mu \mathrm{M}$, Fluence $=417 \mathrm{~mJ} / \mathrm{cm}^{2}$. Here the repetition rate $(\mathrm{rr})=200 \mathrm{kHz}$ and pulse length $=10 \mathrm{ps}$.

\section{P3 Process}

The last P3 laser patterning is related to the counter-electrode insulation. In this process, beside the counter-electrode also the EPH stack is removed to avoid cross-talking between adjacent cells that would result in a reduction of the parallel resistance.[49] By using the same optimized parameters, including fluence, of the $\mathrm{P} 2$ process with $10 \mathrm{ps}, \mathrm{Nd}: \mathrm{YVO}_{4}$, raster scanning laser $(\lambda=355 \mathrm{~nm})$, we were able to obtain an optimized P3 with a width of $25 \mu \mathrm{m}$.

\section{Safety Areas}

In an ideal P1-P2-P3 process, the DA would be only the sum of the widths of these three laser patterns. Nevertheless, since the fabrication process of PSMs requires removing the substrate for material deposition after each laser process, several alignments steps are necessary. In real applications, possible misalignments of the substrate between the three processes can appear, therefore is convenient to introduce a safety area (SA) between P1P2 and P2-P3 (see Fig. 1);. Moon et al. reported a total safety area of $368 \mu \mathrm{m}$, [29] however, aiming to reach ARs higher than $90 \%$, the SA should be strongly reduced. By means of a local CCD camera alignment and a fiducial system based on markers, we were able to set P1-P2 and P2-P3 SA to $50 \mu \mathrm{m}$ each, without compromising the performance of PSMs.

\section{E. Design and fabrication of PSM with an AR of $95 \%$}

The optimized procedure for the $\mathrm{P} 1-\mathrm{P} 2-\mathrm{P} 3$ process will be used in this section for the realization of an optimized module with $\mathrm{AR}=95 \%$.

The design and optimization of PSMs can be made taking into account the geometrical losses due to the presence of DAs, the resistive losses of the FTO and the contact losses due to the limited width of the interconnection areas. These can be resumed in a parameter, named Total Loss (TL).[53, 54] The TL can be expressed as a function of AA width $\left(\mathrm{W}_{\mathrm{A}}\right)$ and $\mathrm{DA}$ width $\left(\mathrm{W}_{\mathrm{D}}\right)$, for a fixed value of $\mathrm{P} 1, \mathrm{P} 3$, and $\mathrm{SA}$ widths and a defined transfer length $\left(L_{T}\right)$ in the $\mathrm{P} 2$ process. The TL is composed by three main parts: geometrical losses due to the realization of DA; Ohmic losses over the AA, due to the non--negligible FTO sheet resistance; Ohmic losses over the interconnection area realized with the P2 step. By extending the procedure in [54] and according to well-known mathematical models, $[53,55,56]$ we can express the TL in terms of module parameters:

Total Loss $=\frac{W_{D}}{W_{A}+W_{D}}+\frac{J_{M P P}}{V_{M P P}}\left(\frac{R_{\square}^{F T O}}{3} \frac{W_{A}^{3}}{W_{A}+W_{D}}+\right.$

$\left.\frac{W_{A}^{2}}{W_{A}+W_{D}} L_{T} R_{\square}^{P 2} \operatorname{coth}\left(\frac{P 2}{L_{T}}\right)\right)$

where $\mathrm{J}_{\mathrm{MPP}}$ and $\mathrm{V}_{\mathrm{MPP}}$ are the current density and voltage at maximum power point of a small area single cell, $R_{\square}^{F T O}$ is the sheet resistance of the active area FTO photo-anode, $R_{\square}^{P 2}$ is the sheet resistance of the interconnection area after the laser ablation of the active layers. In the original model a $R_{\square}^{F T O}$ was considered instead of $R_{\square}^{P 2}$, i.e. without taking into account the possible modification to the FTO surface caused by the $\mathrm{P} 2$ process.

The TL as a function of $\mathrm{P} 2$ and $\mathrm{W}_{\mathrm{A}}$ is shown in Fig. 3, considering a small area single cell with $\mathrm{J}_{\mathrm{MPP}}=17.46 \mathrm{~mA} / \mathrm{cm}^{2}$ and $\mathrm{V}_{\mathrm{MPP}}=838 \mathrm{mV}$, and assuming SA $=50 \mu \mathrm{m}, \mathrm{P} 1=44 \mu \mathrm{m}$ and $\mathrm{P} 3=25 \mu \mathrm{m}$.

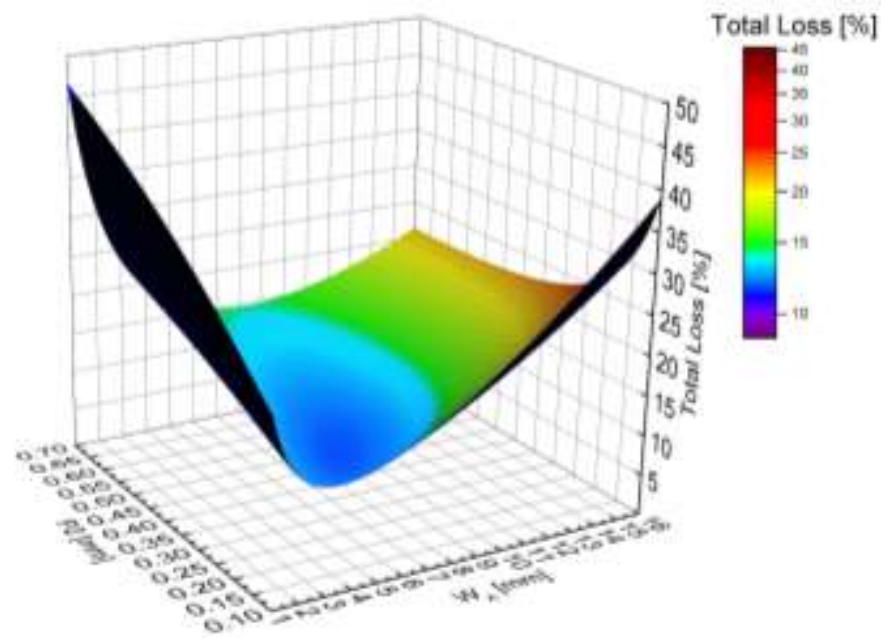

Fig. 3. Total Loss expressed as a function of $\mathrm{W}_{\mathrm{A}}$ and $\mathrm{P} 2$ width, having fixed the reference small area PSC parameters to $\mathrm{J}_{\mathrm{MPP}}=17.46 \mathrm{~mA} / \mathrm{cm}^{2}$ and $\mathrm{V}_{\mathrm{MPP}}=838$ $\mathrm{mV}$, and taking into account SA $=50 \mu \mathrm{m}, \mathrm{P} 1=44 \mu \mathrm{m}$ and $\mathrm{P} 3=25 \mu \mathrm{m}$. It is possible to observe a rapid increase of TL values for small $\mathrm{W}_{\mathrm{A}}$ and large $\mathrm{P} 2$, where geometrical losses dominate the TL and for large $\mathrm{W}_{\mathrm{A}}$ and small $\mathrm{P} 2$, where the resistive part of TL, both over the AA FTO and over the interconnections, dominates.

Fixing the $\mathrm{AR}=95 \%$, we can express the $\mathrm{TL}$ as a function of AA width as shown in Fig. 4. 


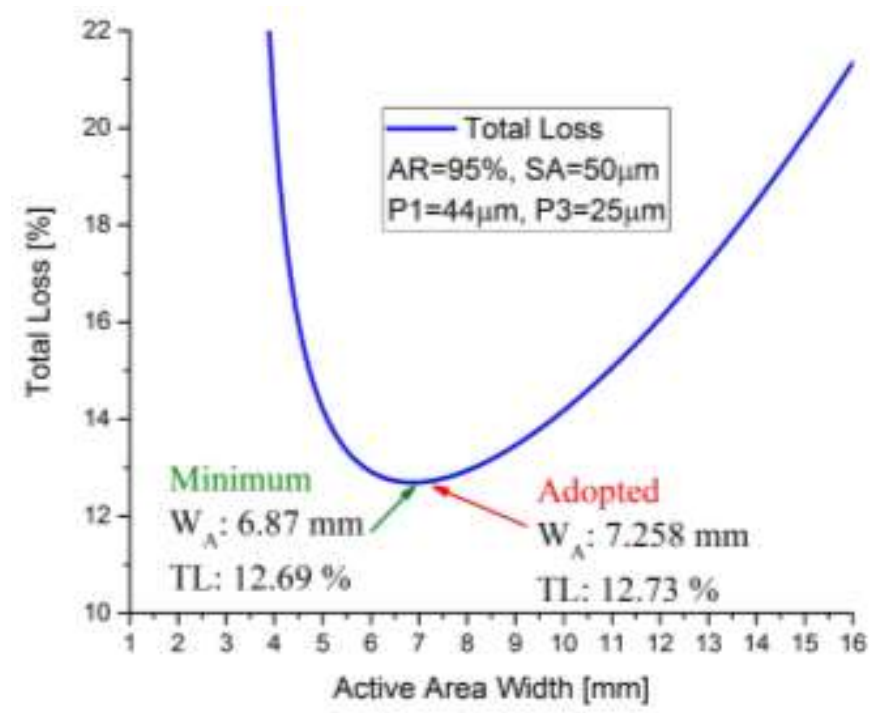

Fig. 4. Total Loss as a function of the AA, for a fixed AR of $95 \%$.

A minimum TL value of $12.69 \%$ is obtained with $\mathrm{W}_{\mathrm{A}}=6.87$ $\mathrm{mm}$, and $\mathrm{W}_{\mathrm{D}}=0.361 \mathrm{~mm}$. Considering the SA, $\mathrm{P} 1$ and $\mathrm{P} 3$ values reported in Fig. 4, the resulting P2 would be of $192 \mu \mathrm{m}$. Owing to the Gaussian shape of the laser beam, we preferred to increase the P2 width up to $213 \mu \mathrm{m}$ in order to ensure the desired etching of the of the EPH stack. As a result we obtain a $\mathrm{W}_{\mathrm{D}}=382 \mu \mathrm{m}$ that, for an $\mathrm{AR}=95 \%$, would require a $\mathrm{W}_{\mathrm{A}}=$ $7.258 \mathrm{~mm}$. As shown in Fig. 4, this deviation only negligibly increases the TL (from $12.69 \%$ to $12.73 \%$ ).

With the design methodology and the optimized values described above, we fabricated PSMs, following the procedure described in the Experimental Details Section, using identical parameters for the four produced samples. The complete DA of one of the realized PSMs is shown in Fig. 5.

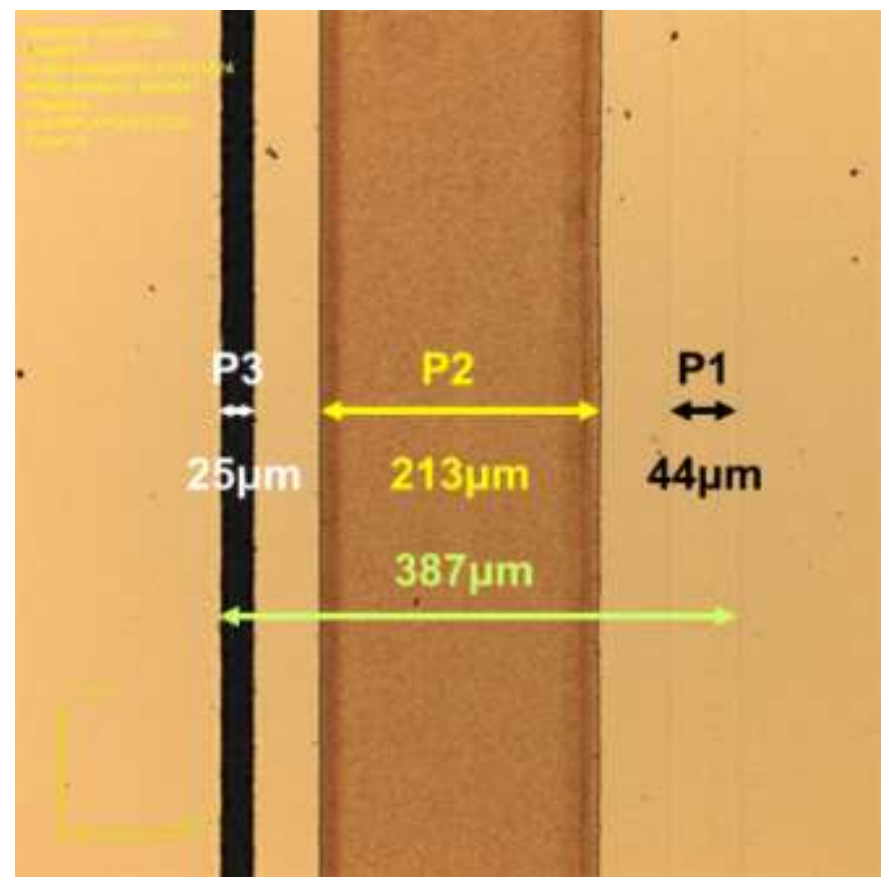

(a)

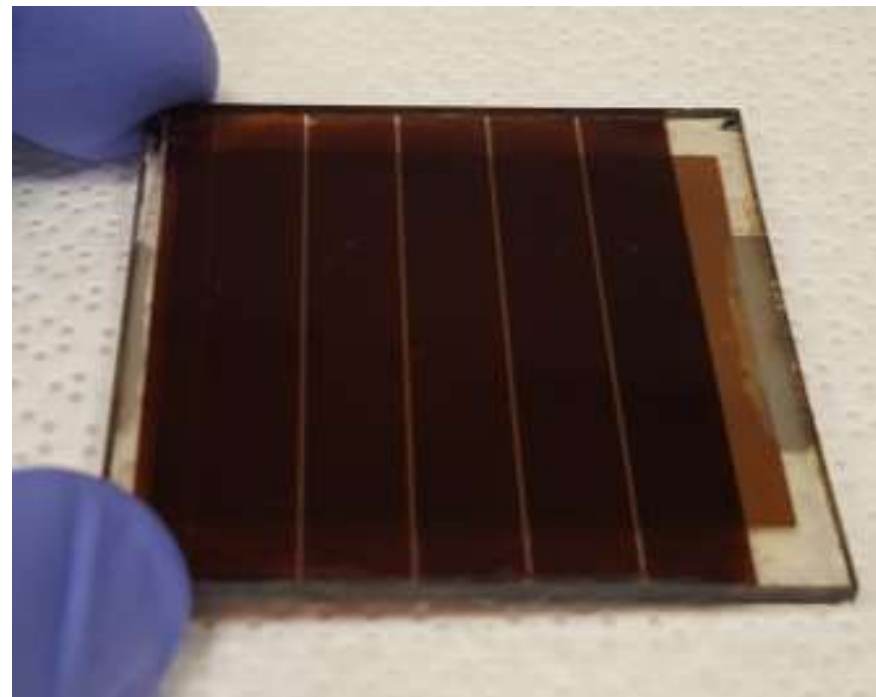

(b)

Fig. 5. (a) Microscope picture of the dead area of a realized PSMs. (b) Picture of a complete module realized on a $5 \mathrm{~cm}$ x $5 \mathrm{~cm}$ substrate.

It is possible to appreciate the clearness of the realized ablation steps, even respect to the previously reported ones.[29] In particular, no laser spots holes are visible, indicating a good overlap between the pulses both in the direction of the raster scanning and in the direction of the horizontal steps of the scanning lines. This is confirmed even by the complete absence of gold exfoliation on the sides of the P3 step line, as, instead, experienced in previously reported literature examples.[29]

In Table II the complete statistics over the four realized PSMs is reported, where a mean PCE $=8.25 \%$ and a mean APCE $=$ $7.8 \%$ have been realized.

These are the highest so far reported values for a large area PSM realized with a fully laser approach.

TABLE II

STATISTICS OF THE REALIZED PSMS

\begin{tabular}{|c|c|c|c|c|c|c|}
\hline SAMPLE & $\begin{array}{c}\text { SINGLE } \\
\text { CELL } \\
\mathbf{W}_{\mathbf{D}} \\
{[\mathbf{c m}]}\end{array}$ & $\begin{array}{c}\text { MODULE } \\
\text { TOTAL } \\
\text { DA } \\
{\left[\mathbf{c m}^{2}\right]}\end{array}$ & $\begin{array}{c}\text { MODULE } \\
\text { AA } \\
{\left[\mathbf{c m}^{2}\right]}\end{array}$ & $\begin{array}{c}\text { AR } \\
{[\%]}\end{array}$ & $\begin{array}{c}\text { PCE } \\
{[\%]}\end{array}$ & $\begin{array}{c}\text { APCE } \\
{[\%]}\end{array}$ \\
\hline 1 & 0.039 & 0.78 & 14.5 & 94.90 & 7.7 & 7.31 \\
\hline 2 & 0.0387 & 0.774 & 14.506 & 94.93 & 7.9 & 7.5 \\
\hline 3 & 0.0392 & 0.784 & 14.496 & 94.87 & 9.3 & 8.82 \\
\hline 4 & 0.0418 & 0.836 & 14.444 & 94.53 & 8.1 & 7.66 \\
\hline
\end{tabular}

Moreover, from Table II we can see that the DA has an average value of $397 \mu \mathrm{m}$ with a Standard Deviation of $15 \mu \mathrm{m}$. The latter permits to consider, in future experiments, a reduction of SAs from $50 \mu \mathrm{m}$ to $10 \mu \mathrm{m}$, allowing for a $\mathrm{DA}=302 \mu \mathrm{m}$ and a corresponding $\mathrm{AR}=96 \%$. 


\section{CONCLUSION}

This work presented a thorough discussion and optimization of the P1-P2-P3 laser process for Perovskite Solar Modules of large area. A Total Loss function has been introduced to account, on the same foot, for the effect of Active Areas, Dead Areas, sheet resistance and transfer length on the module losses The combined use of UV and near-IR Nd: $\mathrm{YVO}_{4}$ lasers, together with a proper optimization of the Total Loss Function permitted to achieve a PSM on an aperture area of $15.28 \mathrm{~cm}^{2}$ with an AR $=95 \%$ and an APCE $=8.82 \%$. Both of these values set records for a fully laser processed large area perovskite based solar module, compared to what has been reported in literature so far. Finally, due to the process precision and repeatability obtained for P1-P2-P3 laser patterning, we have enough room to reduce the safety areas achieving an $\mathrm{AR}=96 \%$.

Due to the sturdiness and scalability of the laser techniques, this work opens the way to the realization of even larger area PSM, in the view of a forthcoming industrialization of this solutionprocess PV technology.

\section{REFERENCES}

[1] N.R.E.L. Best Research-Cell Efficiencies [Online]. Available: http://www.nrel.gov/ncpv/images/efficiency_chart.jp $\mathrm{g}$

[2] K. Yoshikawa, H. Kawasaki, W. Yoshida, T. Irie, K. Konishi, K. Nakano, T. Uto, D. Adachi, M. Kanematsu, H. Uzu, and K. Yamamoto, "Silicon heterojunction solar cell with interdigitated back contacts for a photoconversion efficiency over $26 \%$," Article vol. 2, p. 17032, 03/20/online 2017.

[3] Z. Wang and Z. C. Kang, Functional and Smart Materials: Structural Evolution and Structure Analysis. Springer US, 2012.

[4] M. Saliba, T. Matsui, J.-Y. Seo, K. Domanski, J.-P. Correa-Baena, M. K. Nazeeruddin, S. M. Zakeeruddin, W. Tress, A. Abate, A. Hagfeldt, and M. Gratzel, "Cesium-containing triple cation perovskite solar cells: improved stability, reproducibility and high efficiency," Energy \& Environmental Science, 10.1039/C5EE03874J vol. 9, no. 6, pp. 1989-1997, 2016.

[5] M. Saliba, T. Matsui, K. Domanski, J.-Y. Seo, A. Ummadisingu, S. M. Zakeeruddin, J.-P. CorreaBaena, W. R. Tress, A. Abate, A. Hagfeldt, and M. Grätzel, "Incorporation of rubidium cations into perovskite solar cells improves photovoltaic performance," Science, 10.1126/science.aah5557 vol. 354, no. 6309, p. 206, 2016.

[6] S. D. Stranks, G. E. Eperon, G. Grancini, C. Menelaou, M. J. P. Alcocer, T. Leijtens, L. M. Herz, A. Petrozza, and H. J. Snaith, "Electron-Hole Diffusion Lengths Exceeding 1 Micrometer in an Organometal Trihalide Perovskite Absorber," Science, $10.1126 /$ science. 1243982 vol. 342 , no. 6156, pp. 341344, 2013.
[7]

G. Xing, N. Mathews, S. Sun, S. S. Lim, Y. M. Lam, M. Grätzel, S. Mhaisalkar, and T. C. Sum, "LongRange Balanced Electron- and Hole-Transport Lengths in Organic-Inorganic CH3NH3PbI3," Science, $10.1126 /$ science. 1243167 vol. 342 , no. 6156 , pp. 344-347, 2013.

[8] J. H. Noh, S. H. Im, J. H. Heo, T. N. Mandal, and S. I. Seok, "Chemical management for colorful, efficient, and stable inorganic-organic hybrid nanostructured solar cells," Nano Lett., vol. 13, no. 4, pp. 1764-1769, 2013.

[9] M. Liu, M. B. Johnston, and H. J. Snaith, "Efficient planar heterojunction perovskite solar cells by vapour deposition," Nature, vol. 501, no. 7467, pp. 395-398, 2013.

[10] J. Burschka, N. Pellet, S.-J. Moon, R. HumphryBaker, P. Gao, M. K. Nazeeruddin, and M. Graetzel, "Sequential deposition as a route to high-performance perovskite-sensitized solar cells," Nature, vol. 499, pp. 316-319, 2013.

[11] K. Wojciechowski, M. Saliba, T. Leijtens, A. Abate, and H. J. Snaith, "Sub $150{ }^{\circ} \mathrm{C}$ Processed Mesosuperstructured Perovskite Solar Cells with Enhanced Efficiency," Energy \& Environmental Science, vol. 7, pp. 1142-1147, 2014.

[12] U. Bach, D. Lupo, P. Comte, J. E. Moser, F. Weissörtel, J. Salbeck, H. Spreitzer, and M. Grätzel, "Solid-state dye-sensitized mesoporous $\mathrm{TiO} 2$ solar cells with high photon-to-electron conversion efficiencies," Nature, vol. 395, pp. 583-585, 1998.

[13] P. P. Boix, K. Nonomura, N. Mathews, and S. G. Mhaisalkar, "Current progress and future perspectives for organic/inorganic perovskite solar cells," Mater. Today, vol. 17, no. 1, pp. 16-23, 1// 2014.

N. J. Jeon, J. H. Noh, W. S. Yang, Y. C. Kim, S. Ryu, J. Seo, and S. I. Seok, "Compositional engineering of perovskite materials for high-performance solar cells," Nature, vol. 517, pp. 476-480, 2015.

[15] S. Casaluci, L. Cinà, A. Pockett, P. S. Kubiak, R. G. Niemann, A. Reale, A. Di Carlo, and P. J. Cameron, "A simple approach for the fabrication of perovskite solar cells in air," J. Power Sources, vol. 297, pp. 504510, 2015.

[16] P. Mariani, L. Vesce, and A. Di Carlo, "The role of printing techniques for large-area dye sensitized solar cells," Semicond. Sci. Technol., vol. 30, no. 10, p. 104003, 2015.

[17] O. Malinkiewicz, A. Yella, Y. H. Lee, G. Minguez Espallargas, M. Graetzel, M. K. Nazeeruddin, and H. J. Bolink, "Perovskite solar cells employing organic charge-transport layers," Nature Photonics, vol. 8, pp. 128-132, 2104.

[18] H. Zhou, Q. Chen, G. Li, S. Luo, T.-b. Song, H.-S. Duan, Z. Hong, J. You, Y. Liu, and Y. Yang, "Interface engineering of highly efficient perovskite solar cells," Science, vol. 345, pp. 542-546, 2014.

[19] S. S. Shin, W. S. Yang, J. H. Noh, J. H. Suk, N. J. Jeon, J. H. Park, J. S. Kim, W. M. Seong, and S. I. Seok, "High-performance flexible perovskite solar cells exploiting $\mathrm{Zn} 2 \mathrm{SnO} 4$ prepared in solution below 100 
[thinsp][deg] C," Nature communications, vol. 6, p. 7410, 2015, Art. no. 7410.

[20] P. Qin, S. Tanaka, S. Ito, N. Tetreault, K. Manabe, H. Nishino, M. K. Nazeeruddin, and M. Grätzel, "Inorganic hole conductor-based lead halide perovskite solar cells with $12.4 \%$ conversion efficiency," Nature Communications, vol. 5, p. 3834, 2014.

[21] F. Matteocci, S. Razza, F. Di Giacomo, S. Casaluci, G. Mincuzzi, T. M. Brown, A. D'Epifanio, S. Licoccia, and A. Di Carlo, "Solid-state solar modules based on mesoscopic organometal halide perovskite: a route towards the up-scaling process," PCCP, vol. 16, no. 9, pp. 3918-23, Mar 72014.

[22] J. Seo, S. Park, Y. Chan Kim, N. J. Jeon, J. H. Noh, S. C. Yoon, and S. I. Seok, "Benefits of very thin PCBM and $\mathrm{LiF}$ layers for solution-processed $\mathrm{p}$-i-n perovskite solar cells," Energy \& Environmental Science, 10.1039/C4EE01216J vol. 7, no. 8, pp. 2642-2646, 2014.

[23] F. Matteocci, L. Cinà, F. Di Giacomo, S. Razza, A. L. Palma, A. Guidobaldi, A. D'Epifanio, S. Licoccia, T. M. Brown, A. Reale, and A. Di Carlo, "High efficiency photovoltaic module based on mesoscopic organometal halide perovskite," Prog. Photovolt: Res. Appl., vol. 24, no. 4, pp. 436-445, 2016.

[24] S. Razza, F. Di Giacomo, F. Matteocci, L. Cinà, A. L. Palma, S. Casaluci, P. Cameron, A. D'Epifanio, S. Licoccia, A. Reale, T. M. Brown, and A. Di Carlo, "Perovskite solar cells and large area modules (100 $\mathrm{cm} 2$ ) based on an air flow-assisted PbI2 blade coating deposition process," J. Power Sources, vol. 277, pp. 286-291, 2015.

[25] A. Agresti, S. Pescetelli, A. L. Palma, A. E. Del Rio Castillo, D. Konios, G. Kakavelakis, S. Razza, L. Cinà, E. Kymakis, F. Bonaccorso, and A. Di Carlo, "Graphene Interface Engineering for Perovskite Solar Modules: $12.6 \%$ Power Conversion Efficiency over 50 cm2 Active Area," ACS Energy Letters, vol. 2, no. 1, pp. 279-287, 2017/01/13 2017.

[26] G. Mincuzzi, A. L. Palma, A. Di Carlo, and T. M. Brown, "Laser Processing in the Manufacture of DyeSensitized and Perovskite Solar Cell Technologies," ChemElectroChem, vol. 3, no. 1, pp. 9-30, 2016.

[27] Y. Galagan, E. W. C. Coenen, W. J. H. Verhees, and R. Andriessen, "Towards the scaling up of perovskite solar cells and modules," Journal of Materials Chemistry A, 10.1039/C6TA01134A vol. 4, no. 15, pp. 5700-5705, 2016.

[28] F. Giordano, A. Guidobaldi, E. Petrolati, L. Vesce, R. Riccitelli, A. Reale, T. M. Brown, and A. Di Carlo, "Realization of high performance large area Z-seriesinterconnected opaque dye solar cell modules," Prog. Photovolt: Res. Appl., vol. 21, no. 8, pp. 1653-1658, 2013.

[29] S.-J. Moon, J.-H. Yum, L. Lofgren, A. Walter, L. Sansonnens, M. Benkhaira, S. Nicolay, J. Bailat, and C. Ballif, "Laser-Scribing Patterning for the Production of Organometallic Halide Perovskite Solar
Modules," IEEE Journal of Photovoltaics, vol. 5, no. 4, pp. 1087-1092, 2015.

W. Qiu, T. Merckx, M. Jaysankar, C. Masse de la Huerta, L. Rakocevic, W. Zhang, U. W. Paetzold, R. Gehlhaar, L. Froyen, J. Poortmans, D. Cheyns, H. J. Snaith, and P. Heremans, "Pinhole-free perovskite films for efficient solar modules," Energy \& Environmental Science, 10.1039/C5EE03703D vol. 9, no. 2, pp. 484-489, 2016.

[31] H. Booth, "Laser processing in industrial solar module manufacturing," J. Laser Micro/Nanoeng., vol. 5, no. 3, pp. 183-191, 2010.

[32] L. Rakocevic, R. Gehlhaar, T. Merckx, W. Qiu, U. W. Paetzold, H. Fledderus, and J. Poortmans, "Interconnection Optimization for Highly Efficient Perovskite Modules," IEEE Journal of Photovoltaics, vol. 7, no. 1, pp. 404-408, 2017.

[33] S. Haas, A. Gordijn, and H. Stiebig, "High speed laser processing for monolithical series connection of silicon thin-film modules," Prog. Photovolt: Res. Appl., vol. 16, no. 3, pp. 195-203, 2008.

[34] J. Bovatsek, A. Tamhankar, R. Patel, N. Bulgakova, and J. Bonse, "Thin film removal mechanisms in nslaser processing of photovoltaic materials," Thin Solid Films, vol. 518, no. 10, pp. 2897-2904, 2010.

[35] M. Hueske, "High-Speed Laser Processing in ThinFilm Module Manufacturing," Laser Technik Journal, vol. 7, no. 2, pp. 64-67, 2010.

[36] Y. Galagan, H. Fledderus, H. Gorter, H. H. t Mannetje, S. Shanmugam, R. Mandamparambil, J. Bosman, J. E. J. Rubingh, J. P. Teunissen, and A. Salem, "Roll-toRoll Slot-Die Coated Organic Photovoltaic (OPV) Modules with High Geometrical Fill Factors," Energy Technology, vol. 3, no. 8, pp. 834-842, 2015.

[37] D. K. Schroder, "Contact resistance and Schottky barriers," Semiconductor Material and Device Characterization, Third Edition, pp. 127-184, 2006.

[38] P. N. Vinod, "Specific contact resistance measurements of the screen-printed $\mathrm{Ag}$ thick film contacts in the silicon solar cells by three-point probe methodology and TLM method," Journal of Materials Science: Materials in Electronics, vol. 22, no. 9, pp. 1248-1257, 2011// 2011.

[39] S. Razza, F. Matteocci, F. Di Giacomo, M. Dianetti, A. L. Palma, F. Brunetti, T. M. Brown, and A. Di Carlo, "Large area $(100 \mathrm{~cm} 2)$ Perovskite modules with efficiency exceeding 9\%," in HOPV15, Rome, 10-13 May 2015.

[40] A. Fakharuddin, F. Di Giacomo, A. L. Palma, F. Matteocci, I. Ahmed, S. Razza, A. D'Epifanio, S. Licoccia, J. Ismail, A. Di Carlo, T. M. Brown, and R. Jose, "Vertical TiO2 Nanorods as a Medium for Stable and High-Efficiency Perovskite Solar Modules," ACS Nano, vol. 9, no. 8, pp. 8420-8429, 2015.

[41] A. Fakharuddin, A. L. Palma, F. Di Giacomo, S. Casaluci, F. Matteocci, Q. Wali, M. Rauf, A. Di Carlo, T. M. Brown, and R. Jose, "Solid state perovskite solar modules by vacuum-vapor assisted sequential deposition on Nd:YVO 4 laser patterned rutile TiO 2 
nanorods," Nanotechnology, vol. 26, no. 49, p. $494002,2015$.

[42] G. D. Spyropoulos, C. O. Ramirez Quiroz, M. Salvador, Y. Hou, N. Gasparini, P. Schweizer, J. Adams, P. Kubis, N. Li, E. Spiecker, T. Ameri, H.-J. Egelhaaf, and C. J. Brabec, "Organic and perovskite solar modules innovated by adhesive top electrode and depth-resolved laser patterning," Energy \& Environmental Science, 10.1039/C6EE01555G 2016.

[43] R. Murison, C. Dunsky, M. Rekow, C. Dinkel, J. Pern, L. Mansfield, T. Panarello, and S. Nikumb, "CIGS P1, P2, and P3 laser scribing with an innovative fiber laser," in Photovoltaic Specialists Conference (PVSC), 2010 35th IEEE, 2010, pp. 000179-000184.

[44] F. Matteocci, L. Cinà, E. Lamanna, S. Cacovich, G. Divitini, P. A. Midgley, C. Ducati, and A. Di Carlo, "Encapsulation for long-term stability enhancement of perovskite solar cells," Nano Energy, vol. 30, pp. 162172, 12// 2016.

[45] J. M. Liu, "Simple technique for measurements of pulsed Gaussian-beam spot sizes," Opt. Lett., vol. 7, no. 5, pp. 196-198, 1982/05/01 1982.

[46] F. Matteocci, G. Mincuzzi, F. Giordano, A. Capasso, E. Artuso, C. Barolo, G. Viscardi, T. M. Brown, A. Reale, and A. Di Carlo, "Blocking layer optimisation of poly(3-hexylthiopene) based Solid State Dye Sensitized Solar Cells," Org. Electron., vol. 14, no. 7, pp. 1882-1890, 2013.

[47] W. Shockley, "Theory and Experiment on Current Transfer from Alloyed Contact to Diffused Layer," in Research and Investigation of Inverse Epitaxial UHF Power Transistors - Technical Documentary Report No. AL TDR 64-207 - Appendix B: A. Goetzberger, R. M. Scarlett, AF Avionics Laboratory - Research and Technology Division, Wright-Patterson Air Force Base - Ohio, 1964, pp. 113-130.

[48] G. K. Reeves and H. B. Harrison, "Obtaining the specific contact resistance from transmission line model measurements," IEEE Electron Device Lett., vol. 3, no. 5, pp. 111-113, 1982.

[49] S. Haas, Untersuchung und Optimierung der Serienverschaltung von Silizium-DünnschichtSolarmodulen. Forschungszentrum Jülich, 2010.

[50] G. Mincuzzi, L. Vesce, M. Schulz-Ruhtenberg, E. Gehlen, A. Reale, A. Di Carlo, and T. M. Brown, "Taking Temperature Processing Out of DyeSensitized Solar Cell Fabrication: Fully LaserManufactured Devices," Advanced Energy Materials, vol. 4, no. 14, p. 1400421, 2014.

[51] M. I. Kaganov, I. M. Lifshitz, and L. V. Tanatarov, "Relaxation between electrons and the crystalline lattice," Sov. Phys. JETP, vol. 4, no. 2, p. 173, 1957.

[52] X. Liu, D. Du, and G. Mourou, "Laser ablation and micromachining with ultrashort laser pulses," Quantum Electronics, IEEE Journal of, vol. 33, no. 10, pp. 1706-1716, 1997.

[53] Y. Gupta, H. Liers, S. Woods, S. Young, R. DeBlasio, and L. Mrig, "Optimization of a-Si solar cell current collection," in 16th Photovoltaic Specialists Conference, 1982, pp. 1092-1101.
[54] B. Turan and S. Haas, "Scribe width optimization of absorber laser ablation for thin-film silicon solar modules," Journal of Laser Micro Nanoengineering, vol. 8, no. 3, p. 234, 2013.

[55] J. Hüpkes, J. Müller, and B. Rech, "Texture Etched ZnO:Al for Silicon Thin Film Solar Cells," in Transparent Conductive Zinc Oxide: Basics and Applications in Thin Film Solar Cells, K. Ellmer, A. Klein, and B. Rech, Eds. Berlin, Heidelberg: Springer Berlin Heidelberg, 2008, pp. 359-413.

[56] H. B. Harrison, "Characterizing metal semiconductor ohmic contacts," Proceedings of the IREE Australia, vol. 41 , p. $95,1980$. 